\title{
O som ao redor (2012): ecografias jurídicas do autoritarismo brasileiro
}

\author{
"The sound around" (2012): legal ecographs of brazilian \\ authoritarism
}

(iD) Maria Cristina Vidotte Blanco Tárrega ${ }^{1}$

(iD) Pedro Henrique Corrêa Guimarães ${ }^{2}$

\begin{abstract}
"antes de existir computador existia tevê
antes de existir tevê existia luz elétrica antes de existir luz elétrica existia bicicleta antes de existir bicicleta existia enciclopédia antes de existir enciclopédia existia alfabeto antes de existir alfabeto existia a voz antes de existir a voz existia o silêncio"
\end{abstract}

(Arnaldo Antunes)

\begin{abstract}
1 Pesquisadora e extensionista. Mestre em Direito Civil e Doutora em Direito Empresarial pela PUC SP, é professora titular da Universidade Federal de Goiás, nos Programas de Pós Graduação em Direito Agrário e no Doutorado da Rede Pro Centro Oeste de Biotecnologia Biodiversidade, e no Programa de Mestrado da Universidade de Ribeirão Preto.Pesquisadora bolsista produtividade do CNPq, fez estágio pós doutoral na Universidade de Coimbra. Atua em Grupos de Pesquisa (2000-atual), dedicando-se às questões de direito empresarial e societário, da propriedade intelectual na exploração econômica da biodiversidade, etnodesenvolvimento e sustentabilidade, produção agrícola integrada, sob uma perspectiva das comunidades tradicionais quilombolas, dos direitos coletivos, do pluralismo jurídico e da democracia participativa. É membro da Rede para o Novo Constitucionalismo Democrático Latino Americano. Leciona hermenêutica constitucional e direito empresarial. Direitos das minorias e grupos vulneráveis, Teoria Geral do Direito Agrário e Tópicos em Biodiversidade e Biotecnologia. Autora de várias obras de direito. Tem experiência em orientação de pesquisas e extensão, teses, dissertações e trabalhos de conclusão de cursos. Organizou e participou de eventos nacionais e internacionais. Apresentou trabalhos e proferiu palestras no Brasil e no exterior. Participou bancas de concursos em universidades públicas, concursos públicos outros, bancas de mestrado, doutorado. É avaliadora do INEP, supervisora da SESu (ad hoc) e parecerista CNPq (ad hoc). É avaliadora ad hoc da Capes, FAPEG e FAPEMIG. Integra o Conselho Editorial de vários periódicos científicos. É editora da Revista da Faculdade de Direito da UFG E-mail: mcvidotte@gmail.com. ORCID: https://orcid.org/0000-0002-4805-4345. CV: http://lattes.cnpq.br/3710736362842934.

2 Doutorando em Direito Agrário (PPGDA/UFG - Bolsista Fapeg). Mestre em História (UFG). Foi Advogado atuante na área Cível e Administrativa e Docente na Faculdade de Direito de Inhumas (FacMais). Foi docente na Faculdade Morgana Potrich (Mineiros-GO) e no Instituto Unificado de Ensino Superior (IUESO-GO). Foi Coordenador do Núcleo de Prática Jurídica da Fama/Mineiros (2015) e Coordenador do Cejusc Mineiros (2015). E-mail: pedro_correa@discente.ufg.br. ORCID: https://orcid.org/0000-00018920-9772. CV: http://lattes.cnpq.br/2181276043598011.
\end{abstract}


Resumo: O Som ao redor (2012) é um filme brasileiro produzido e roteirizado por Kléber Mendonça Filho. O filme aborda a transformação do imaginário da violência no Brasil do Século XX e o transbordamento de uma máquina tecnojurídica de produzir silenciamentos, em que a normatividade funde-se ao caos. O trabalho tem perspectiva metodológica da análise do discurso, numa vertente materialista. Os objetivos consistem em interrogar as estruturas de sentido e os seus desvios e para alcançar a historicidade constitutiva das milícias e de violências contemporâneas.

Palavras-chave: O Som ao Redor. Silenciamento. Subjetividades.

Abstract: O Som ao redor (2012) is a brazilian film produced and scripted by Kléber Mendonça Filho. The film deals with the transformation of the imaginary of violence in Brazil in the 20th century and the overflow of a techno-legal machine to produce silences, in which normativity merges with chaos. The work has a methodological perspective of discourse analysis, in a materialistic aspect. The objectives are to question the structures of meaning and their deviations and to reach the constitutive historicity of contemporary militias and violence.

Keywords: Som ao Redor. Silencing. Subjetivities.

Data de submissão do artigo: Junho de 2021

Data de aceite do artigo: Julho de 2021 


\section{Introdução}

O cinema brasileiro mostra a realidade local. Essa é uma importante característica. Assim é $O$ som ao redor, de Kleber Mendonça Filho $^{3}$. E o é da forma mais realista possível, de um realismo mundano. O cenário é a rua onde viveu o diretor, com seus sons, seus vizinhos suas relações sociais. A representação da localidade é marca da película cujas cenas foram filmadas na Rua José Moreira Leal, no Recife, onde na ocasião morava o diretor. Alí o diretor colheu os sons e os sentidos desviados a partir deles: o som ao redor.

A narrativa é tecida a partir desses sons. Eles impulsionam os sentidos e vão deslocando a trama do cotidiano das vidas comuns. Vidas que reproduzem as estruturas patriarcais forjadas no capitalismo colonial brasileiro. É a reprodução de um engenho, que propõe a metáfora de um "tapete de áudio onde deslizam os sentidos e se sobrepõem múltiplas camadas discursivas". Como no teatro de João das Neves, são muitas tramas são tecidas, sem personagem principal, central do enredo 4 .

A história se desenvolve em Pernambuco. Manuel Correa de Andrade (2001) nos ensina que até a metade do século $X X$, Pernambuco foi o principal produtor nacional de açúcar. Porém, essa economia conheceu um retrocesso posteriormente. Numerosas usinas encerraram suas atividades industriais com importantes consequências sociais. Houve um processo de esfacelamento das propriedades rurais, que a película retrata nas cenas que se passam no Engenho. Dessa forma, elites rurais passaram a ser os investidores na expansão das cidades e dos projetos imobiliários na virada so século XX e primeiras décadas do XXI.

\footnotetext{
3 Ficha Técnica Completa: Direção e Roteiro: Kleber Mendonça Filho;Produção: Emilie Lesclaux;Direção de Fotografia e Câmera: Pedro Sotero e Fabricio Tadeu;Direção de Arte: Juliano Dornelles;Montagem: Kleber Mendonça Filho e João Maria;Desenho de Som: Kleber Mendonça Filho e Pablo Lamar;Som Direto: Nicolas Hallet e Simone Dourado;Trilha Sonora: Dj Dolores;Assistente De Direção: Clara Linhart;Direção de Produção: Brenda Da Mata \& Renato Pimentel;Produção de Elenco: Daniel Aragão;Preparadores de Elenco: Amanda Gabriel, Leonardo Lacca;Maquiagem: Marcos Freire;Figurino: Ingrid Mata;Elenco: Irandhir Santos, Gustavo Jahn, Maeve Jinkings, Waldemar José Solha, Irma Brown, Lula Terra, Yuri Holanda, Clébia Souza;

4 Sobre as dimensões do teatro do João das Neves podemos ler BATISTA, N. C. Dimensões políticas e estéticas do trabalho de João das Neves: uma análise do processo de formação de atores não profissionais em O Último Carro (1976-1978). Pitágoras 500, Campinas, SP, v. 9, n. 2, p. 47-64, 2019. DOI: 10.20396/pita.v9i2.8656696. Disponível em: https://periodicos.sbu.unicamp.br/ ojs/index.php/pit500/article/view/8656696. Acesso em: 20 maio. 2021.
} 
Observa o geógrafo (ANDRADE, 2001) que a cultura sucroalcooleira e sua expansão no período de quatro séculos foi determinante das relações sociais, "plasmando uma sociedade e uma civilização". A sociedade foi estruturada rigidamente em classes, com poderes simbólicos bem definidos, mantidos por deslocamentos de sentido que faz perdurar até os dias atuais. O reconhecimento social das esferas de poder na estrutura de classes engendrada naquela sociedade consegue se manter com os desviantes de sentido. Na película, o senhor do engenho é o senhor da rua, e dando continuidade ao modelo de criadagem, as empregadas domésticas são tratadas como "coisas" dos empoderados.

Essa história nordestina está referida na abertura do filme. Imagens em preto e branco devolvem o espectador ao ambiente rural do nordeste brasileiro, à Casa-grande e senzala, de Gilberto Freyre, ao escravismo colonial, tudo o que irá significar a sociedade pernambucana, e a brasileira. A tensão entre classes, que permeia toda a película, também está na abertura do filme, nos registros das Ligas Camponesas lideradas por Francisco Julião, nas referências ao líder camponês João Pedro Teixeira e sua esposa, Elizabeth Teixeira, personagens do filme Cabra Marcado para Morrer (1984), de Eduardo Coutinho.

As cenas do realismo mundano de $O$ som ao redor revelam uma realidade mais ampla do que aquela mostrada na superfície de sentidos. Aporta o interdiscurso como objetividade material contraditória (ORLANDI, 2007). Nos traz as origens violentas do patriarcado agrícola colonial latifundiário que dá origem ao modelo miliciano. Coloca-nos frontalmente (apresentada metaforicamente na película com a maioria das tomadas de cena estáticas frontais) com a experiência social do Brasil contemporâneo.

Nesta perspectiva patriarcal é possível analisar todas as assimetrias sociais e a violência contra a mulher, base de todas as outras formas de violência e dominação (SEGATO, 2018). Esses sistema político e econômico, fundante de um capitalismo constitutivo de um universo de sentido violentador, agressivo, destruidor do campo feminino é trazido a tona na película. 
Muitos aspectos podem ser estudados nessa importante obra do cinema brasileiro, deslevando camadas, pegando atalhos de sentido. A nossa proposta primeira é refletir sobre as origens históricas das milícias nessa realidade social desviante que, no movimento dos sentidos, preserva suas estruturas políticas, garantidas pela normatividade posta. Por outro lado, buscamos compreender os ruídos e os silenciamentos sociais desvelados na película e suas razões históricas.

Buscamos situar nossa reflexão na perspectiva conceitual e metodológica da análise do discurso de fundamento material, sobretudo a partir dos estudos de Orlandi (2007). A crítica nos exigiu, outrossim, o aporte de algumas reflexões filosóficas.

\section{O milicianismo e o imaginário da violência na sociedade brasileira contemporânea}

O filme de Mendonça Filho de 2012 traz um questionamento sobre as subjetividades contemporâneas e a violência urbana a partir de um enredo que se desenvolve em um bairro de classe média na cidade do Recife. O estrato da violência é marca do cinema brasileiro, em películas de destaque como Cidade de Deus (2002), Tropa de Elite (2007/2010). Nesses filmes a violência gira em torno da atividade policial e sua malfada guerra ao tráfico; O Som ao redor, de outro modo, trata do problema das milícias.

Mendonça Filho há nove anos prenunciou o que se tornou um problema revelavante da política brasileira: a emergência das milícias com o aumento da violência urbana e a desconfiança sistêmica da polícia. Esse panorama abre espaço para um cenário de privatização da segurança pública, deixando emergir, assim, as milícias.

Milícias têm raízes se encontram na estrutura patriarcal violenta, como nos mostra este filme. Elas podem ser entendidas também como um desvio ou uma variação do sentido do jagunço, 
O som ao redor (2012): ecografias jurídicas do autoritarismo brasileiro

Maria Cristina Vidotte Blanco Tárrega • Pedro Henrique Corrêa Guimarães

da vingança. A película mostra um deslocamento de sentidos mobilizando a acomodação dos poderes locais, originalmente ancorado na estrutura social gerada pelos engenhos de açúcar, agora nos empreendimentos imobiliários.

C. Masson e V. Marçal (2016) apontam que as milícias no Brasil existem desde a época do império. Como se observa no filme, ela tem origem (ou reproduz, ou mesmo dá continuidade) na violência do patriarcado agrícola brasileiro, no capitalismo latifundiário, no autoritarismo, na opressão entre classes, na dominação e na arrogância das oligarquias locais. Contudo, o conceito e a atividade miliciana sedimentou-se no final do século $X X$, notadamente em comunidades carentes, diante da omissão estatal. Na contemporaneidade, ela se caracteriza pelo oferecimento coercitivo de serviços de segurança privada e outros serviços; normalmente é integrada por ex-policiais e ex-militares ${ }^{5}$.

A legislação define milícia como uma organização criminosa, tal qual disposto no Artigo $1^{\circ}, \S 1^{\circ}$ da Lei $12.850 / 2013$. Todavia, a definição legal esconde um problema crimonológico, porquanto a milícia não se confunde com as organizações criminosas do tráfico de entorpecentes, tais como o PCC (Primeiro Comando da Capital) e o Comando Vermelho, devido as atividades por eles desenvolvidas não estarem adstritas à marginalidade penal específica.

Na organização miliciana as atividades são variadas de segurança privada à venda de botijões de gás. A milícia desenvolve concomitantemente atividades legais e ilegais, e em muitos casos com a conivência estatal. Assim ela está entrelaçada na atividade estatal regular.

No jogo miliciano, a legalidade e a ilegalidade se fundem e a estrutura de opressão opera como um substituto da ordem estatal (oferecimento de serviço de segurança que deveria ser público)

\footnotetext{
5 Os que compõem as milícias de ex-policiais sequer são paramilitares. São militares que abusam do monopólio da violência garantida pelo Estado, que Ihes fornece treinamento e armas. São os que têm ou tiveram a função de garantir o cumprimento da lei, mas agem ao arrepio da lei, contra a lei, não só para fazer da segurança um negócio lucrativo, mas também para explorar, em muitos outros empreendimentos, os mais vulneráveis entre os trabalhadores urbanos, aqueles que não têm garantias legais na habitação, não tem acesso à Justiça e à informação, não têm protetores institucionais nas localidades onde vivem. (ZALUAR, Alba; CONCEIÇÃO, Isabel Siqueira. Favela sob o controle das milícias no Rio de Janeiro que paz? São Paulo em perspectiva. v. 21, n. 2, p. 89-101. 2007. Disponível em: Acesso em: 08 janeiro 2021
} 
e, ao mesmo (ainda que paradoxalmente), sustenta-se a partir do aparato estatal jurídico e policial.

Ademais, como muitas milícias são formadas também por policiais em atividade, em muitos casos a atividade policial confunde-se com a atividade miliciana ${ }^{4}$.

Bruno Paes Manso (2019), traçou um panorama psicopolítico6 do tipo miliciano a partir de uma entrevista com ex-miliciano que chamou de Lobo. Para este autor, o miliciano não é um psicopata, nem alguém que tem vontade de matar e exterminar, mas aquele que acredita estar realizando uma função de manutenção de certa ordem social ("agir em defesa da comunidade", como nomeia). O relato trazido por Paes Manso (2019) é interessante porque a milícia não deve ser vista apenas como um comportamento desviante, ou exclusivamente agrupamento marginal; é uma forma de regência política a partir manifestações de micropoderes (poderes locais) que se expandem em tendência hegemônica.

O milicianismo é uma racionalidade político-social A milícia é uma das formas de privatização da ordem pública e por também é uma forma de organização típica das sociedades neoliberais (do mesmo modo que o neoliberalismo é uma racionalidade econômico-social como assinalou Dardot e Laval [2019]6).

A milícia é o reflexo de um discurso (racionalidade) de supressão da ordem pública que desemboca na área de segurança pública. Não é por acaso que as milícias se fortalecem com o enfraquecimento da atividade estatal de assistência social.

E essa racionalidade que emerge do descrédito da ordem pública que fez com que surgisse a figura de Jair Bolsonaro, como assinalou Paes Manso (2019). O bolsonarismo, tal qual o milicianismo, age a partir da lógica miliciana emergindo a partir de um discurso duplo, ambíguo e cínico. Ele instaura o caos a partir do discurso da ordem. A milícia é um agenciamento (no sentido deleuziano8) produtor de um duplo ordem/caos.

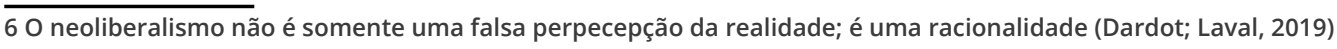


Peter Sloterdjik (2012), filósofo alemão, nota bem essa expansão de uma racionalidade cínica na contemporaneidade7. Na atualidade, o cinismo é diferente do cinismo antigo, porquanto desprovido de qualquer potência transformadora. No mundo antigo, Diógenes, o filósofo cínico questiona o poder de forma bufante. Ao ser questionado pelo imperador Alexandre, o Grande, o que poderia ele fazer por Diógenes, o filósofo respondeu: "saia da frente, porque está tapando o sol". Ou seja, o cinismo é usado para questionar o poder político. Nos tempos contemporâneos, ao contrário, o cinismo se funde ao poder político.

O filme de Mendonça Filho é exemplar ao demonstrar como a milícia atual age de forma cínica (no sentido contemporâneo). Primeiramente, porquanto, a dita segurança privada coordenada pela personagem de Clodoaldo não questiona o poder político financeiro (representado pelo personagem Francisco), e ainda porque ela continua tolerar práticas criminosas na região (ao não impedir que o vendedor de água realizasse o tráfico de drogas).

Como se vê em Som ao Redor, a milícia segue a lógica neoliberal e passa a combater diretamente somente aqueles que estão fora da ordem econômica (da ordem de produção de lucro). Em uma cena emblemática do filme, os milicianos de Clodoaldo agridem um menino preto que se esconde na região, ainda que não fosse conhecida a razão de ele estar sobre a árvore no bairro. Observase aí como o sentido dado no interdiscurso prevalece: "O negro na noite, é ladrão."

Na sociedade brasileira contemporânea a milícia é a forma de poder consolidada, porquanto gere uma produção (e pulsão) de vida (biopolítica) e de morte (necropolítica) que transcende à esfera pública. Ela é a cristalização do apagamento da fronteira do público com o privado (ou de forma mais radical, e a cooptação e captação do público pelo privado), o que é também marcante no bolsonarismo.

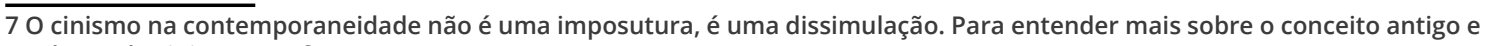
moderno de cinismo, conforme SLOTERDIJK (2012). 
Todavia há um aspecto mais sutil, além da transformação social das estruturas de poder politico locais e central, que o milicianismo revela: a mutação do imaginário social da violência. $O$ desvio do sentido no plano ideológico que garante a hegemonia. Não se pode perder de vista que a milícia emerge a partir de um discurso da segurança (e esse aspecto tem passado à margem dos comentaristas). E o que é a segurança? O que ampara o clamor social por segurança?

É preciso pôr em tela (mise-en-scene) o que a segurança quer assegurar: o status quo, a conservação das relações de poder. E conservar uma forma de poder é sempre deixar aparecer a violência. Um poder assegura-se sempre pela violência. E assim sendo, a segurança ecoada - e aqui o primeiro som ao redor - é a conclamação de uma ameaça velada de violência.

Permita-nos uma cena de digressão exemplificativa e explicti-

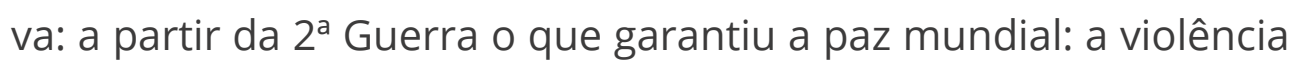
sublimada da bomba atômica. A segurança mundial é sustenta hoje pela bombas atômicas que evocam a destruição total. A segurança é assim uma violência totalitária que emerge como discurso.

Em segunda tela, os discursos de segurança põem em cena aquilo que o filósofo alemão Peter Sloterdijk (2009) chama de "sociedade do mimo"8. A "sociedade do mimo" é aquela em que a vida social está presa em uma bolha apartada do mundo natural, em que as pessoas creem que os riscos estão controlados. Nesses cenários os discursos de segurança encontram guarida. Quando o mundo social, natural, política desmorona-se a segurança é a memória de um paraíso perdido, de um passado utópico em que se acreditar poder dominar o mundo. E essa totalização (talvez hegeliana) não é mais possível.

A violência miliciana põe em cena a passagem da sociedade de vigilância (conforme nomeados por Michael Foucault [2014]) para uma sociedade de controle a partir de ferramentas tecnológicas (ou tecnocráticas).

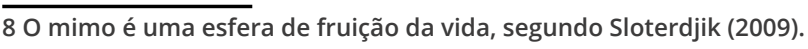


Para Deleuze (2000) as sociedades de controles são aquelas em que há uma crise generalidazada dos sistemas de vigilância. Essa crise de vigilância faz nascer (ou permite nascer) uma forma de exercício do poder no qual há uma "moratória ilimitada", uma opressão contínua e velada, uma "deformador universal" da segurança. Nessas sociedades, o poder é "ondulatório, funcionando em órbita, num feixe contínuo".

Nas sociedades de controle o poder é exercido não a partir dos meios físicos, seja na formas das arquiteruras de vigilância, seja no uso de armamento. O poder está entremeado na própria estrutura de propagação da informação. Ela é assim tecnocrática. Há uma estrutura semiótica (e rizomática) dos regimes de opressão. E essa transformação modular é audível em O Som ao redor.

No filme de Mendonça Filho há uma cena exemplar dessa virada tecnoimaginária (psicoesférica9) da violência (e no seu exercício). A personagem João pergunta ao miliciano Clodoaldo se ele exerceria seus serviços de vigilância a partir do uso de armas de fogo. O miliciano responde de forma ambígua e cínica (própria da linguagem miliciana). "sim e não"; em seguida ele mostra a João um celular e diz: "essa é minha arma".

E por que o celular é tratado como uma arma? O enredo revela alguns desses momentos: é uma arma porque a partir dela se ameaça os ditos meliantes (como a personagem Dinho) e uutros moradores. Além disso, o celular dá acesso a câmeras de controle da circulação na região. Pelo celular Clodoaldo pode ser contatado a qualquer momento pelos seus 'agentes'. Em nenhum momento do filme os personagens utilizam uma arma de fogo ou um arma branca. Há apenas uma insinuação na cena final do filme, em que o suposto barulho de um tiro de arma de fogo é substituído por barulhos de fogos de artifício. Essas não aparecem, não fazem parte dessa cinematrografia. No entanto, a milícia exerce poder, apavora e coage os moradores.

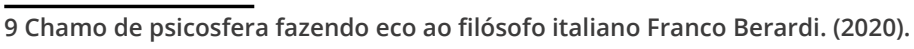


Assim, a milícia é essa máquina cínica e pós-moderna do exercício do poder. Ele é própria das sociedades de controle, posto que exerce um poder deformador rizomático. O poder miliciano não é um poder explícito (policial) nem um poder geográfico (do tráfico). O poder miliciano é um poder que se exerce de forma velada, ambígua. Ele se exerce sem a força física explícita, é uma força velada, totalitária. É uma força simbólica que permeia no imaginário social. É um duplo: um discurso legal e paralegal ao mesmo tempo. O Som ao Redor é preciso ao cinematografar esse cenário.

\section{A sociedade do ruído e as subjetividades barulhentas e silenciadas}

"O que é o som? Porque o som ao invés do silêncio? O que o som silencia e o que o silêncio grita?" Essas perguntas ambíguas e paradoxais são condutores do filme de Mendonça Filho. O enredo produz e deixa produzir esses cenários duplos, deseconstrutivos, ecoacústicos.

Nota-se que em nenhuma cena do filme há completo silêncio. Houve um esforço sonoplástico da produção10 para que o espectador sempre deparar-se com um som: da cachoeira ao latido do cão. Da bola insistente e solitária. O incômodo da solidão, da ausência de significado - o nada. Há um excesso intencional de som, de forma que o ruído sempre esteja presente. O silêncio fundante, constitutivo é calado pelo ruído permanente. Os sons, os barulhos circundantes, os barulhos cotidianos do real mundano classe média, variantes de sentido, estabelecendo pontos de fuga para os escontros com o espectador. Orlandi (2007) nos diz que onde há silêncio há sempre a possibilidade de os sentidos migrarem para outros objetos simbólicos. O sentido não é estático. É preciso detê-lo para realizar o controle ideológico-

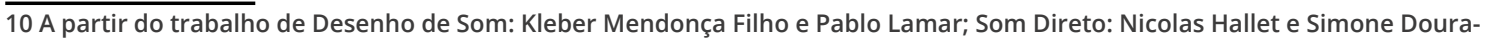
do; Trilha Sonora: Dj Dolores 
Assim, nesse jogo cinematográfico está presente também uma característica exemplar das sociedades contemporâneas: somos sociedades de ruídos.

Fernand Braudel (1949), historiador francês, ao descrever as transformações espaciais e temporais do mundo medieval para o mundo moderno, diz que ao habitar cidades o homem passou a conviver continuamente com o ruído.

O mundo da cidade é o mundo do ruído e o silêncio total é impossível. Estamos sempre imersos em algum tipo de som: de pessoas, de máquinas, de carros, de ambulâncias. E esse excesso de som exerce um papel ambíguo: é irritante e excitante, ao mesmo tempo. Mas, controla o imaginário. Conduz e censura e impõe direcionamentos.

A personagem Bia é paradigmática nesse sentido. Ao mesmo tempo que se excita e busca o gozo a partir do barulho de uma máquina de lavar roupas, se irrita e se sente bastante incomoda com os latidos de um cachorro, tentando-o silenciar com uma máquina de produzir ruídos microfrequência e em por fim, com o estouro de fogos de artifício.

O ruído assim é o elemento de excitação social - a música, as conversas altas dos bates, os roncos do motor de carros e motos, as batidas frenéticas da construção civil. E também é, concomitantemente, um elemento depressor - as dores causadas pelo barulho, as brigas de vizinhos por conta do som alto, as infrações às normas do estatuto da vizinhança (a poluição sonora). Esses estados de excitação/depressão alternados são muito presentes na psique de indivíduos contemporâneos, gerando comportamentos bipolares (transtorno de personalidade bipolar), ou ainda síndromes de Burnout, que Byung-Chul Han (2015) elenca como o estado psíquico do sujeito contemporâneo, por excelência.

Ao produzir excitações e depressões o som é também uma máquina de produção de subjetividades (como chamou Felix Guattari [1992]). E somos subjetividades barulhentas. A subjetividade não é da ordem interna, ela é produzida externamente. No 
mundo contemporâneo, o discurso econômico neoliberal produz subjetividades barulhentas, porquanto, nesse cenário, cessar a ação confunde-se com o cessar da produção de dinheiro.

Chul Han (2017) afirma que nas sociedades contemporâneas o indivíduo se explora para produzir a riqueza. O Si mesmo (conclamando uma categoria foucaultina11) é como a fábrica, e por isso ficar em silêncio é tão difícil para o sujeito contemporâneo.

Essas subjetividades barulhentas também produze a opressão do Outro. Essa opressão silenciadora perpassa a obra de Mendonça Filho e pode ser na constituição das personagens femininas e nas personagens das trabalhadoras domésticas. Em todas as casas da classe média recifense retratadas em O Som ao Redor existe uma empregada doméstica explorada e marginalizada, em que impera uma hierarquia das classes: trabalhadora/patroa, trabalhadora - negra/patrões senhores do capital. As características dos agregados, originários do escravismo colonial estão claramente presentes na relação de João com toda a família da domestica, na relação servil, na generosidade e na tolerância do senhorzinho em compartilhar a "casa grande" com a criadagem.

No início do filme a personagem João sempre interrompe e corta a voz de Maria, namorada dele (maninterupting); ela demora a conseguir dizer que o carro de Sofia tinha sido arrombado. Essa é a razão pela qual ela diz que gostaria de se aposentar, queria dizer que queria libertar daquela estrutura de silenciamento.

O mesmo ocorre com a filha de Maria, a passadeira, cuja voz é quase imperceptível (ou inaldível). Escuta-se apenas seu patrão dando ordens, "cuidando", sugerindo. É um monólogo que enncaminha pontos de fuga para o sentido da relação servil e escravocrata, historicamente estabelecida.

A violência contra as empregadas domésticas também é demonstrada no filme, na cena agressão verbal da personagem Bia. Após essa danificar o aparelho de ultrassom da residência. Essa violência, entretanto, não impõe o silêncio e não revela a mesma

11 Sobre a constituição da subjetividade como si-mesmo ver: FOUCAULT, M. A hermenêutica do sujeito. São Paulo: WMF Martins Fontes, 2010 
fragilidade na relação. No caso a patroa pertence a uma classe menos ponderosa.

Há ainda o silenciamento simbólico da empregada doméstica de Francisco, que precisa se despir do traje de trabalho para se tornar gente e desfrutar dos prazeres da vida. O uniforme de trabalho é o "calar" do sujeito. É a censura. Silencia a pessoa e a invizibiliza. Como afirma Orlandi (2007), onde há censura, há resistência. Desnudado do véu que a oculta e liberta do tapa que the cala, a empregada de Francisco leva o personagem miliciano de Clodoaldo à transgressão. Ele viola a casa que deveria cuidar. Ela o leva à cama dos donos da casa que estava sob os cuidados dele.

Percebe-se, nessas cenas, o que Rita Laura Segato (2012) chama de "patriarcado colonial moderno", em que o machismo está entremeado pelo colonialismo e o escravagismo. Há uma dupla opressão sobre a mulher brasileira: de gênero e socioeconômico (exercidos concomitamente e uma forma entrelaçada na outra - o double bind de Derrida [1995]).

Na sociedade brasileira, essa exploração do trabalho feminino doméstico é ainda a reprodução de uma estrutura escravocrata/ colonial - numa repetição do engenho12. Veja, que no filme as empregadas domésticas são sempre mulheres pretas, exploradas de diferentes formas e com diferentes nuances, mas nunca livres.

Racismo, machismo e exploração do trabalho é assim uma tríade que caracteriza a sociedade brasileira, e essa é muito bem demonstrada no filme de Kléber Mendonça Filho. E esse imaginário social de base que dá impulso ao acolhimento pela classe média recifense da milícia.

O ruídos históricos da sociedade brasileira é produtora de silenciamentos profundos. Esse parece ser o leitmotiv de $O$ som ao redor, ainda que seja não haja um enredo linear clássico na trama.

12 MENDONÇA FILHO, Kleber. O som ao redor. O país do cinema. Disponível em:

https://www.youtube.com/watch?v=ijAl3WcNwQI. Acesso em 10/01/2021. Repetição que é não só uma reposição histórigráfica, é um contínuo que produz a diferença. 


\section{Tímpanos: e a escuta jurídica do social}

O ruído sempre foi um desafio à filosofia. Para Pascal a infelicidade do homem decorre da impossibilidade do silêncio em casa. Para Schopenhauer a cacofonia é a tortura do filósofo. Nietzsche teve uma crise nervosa ao ouvir os estalos de um chicote sobre o cavalo.13 o ruído contrasta com o pensamento, em seu estado de isolamento acústico, tal que propõe a imagem esculpida por Rodin.

Jacques Derrida (1991), filósofo francês, em sua segunda fase desconstrutiva procurou timpanizar a filosofia14. Como essa expressão (quase-conceito), Derrida quis desvelar os espaços intervalares - nem dentro, nem fora - um duplo ambíguo transespacial.

Esses mesmos espaços intervalares devem ser revelados pelo pensamento jurídico, que tradicionalmente ficou preso entre os jogos duais de Estado/Sociedade; legalidade/moralidade.

Esse jogo dicotômico deixa passar a margem o pensamento miliciano/neoliberal que se infiltrou sobre o tecido socioestrutural das subjetividades de modo que os indivíduos passam a reproduzir formas de comportamento violento que não são nem mesmo descritos pelo direito.

O Direito moderno, desde Kelsen, ainda que tenha conquistado certa autonomia científica quis blindar-se os ruídos sociais, e acabou não conseguindo acompanhar as transformações sociais. $\mathrm{O}$ direito ficou à margem da sociedade.

A emergência das milícias e do neoliberalismo deixam claros esse deslocamento do direito. A ordem jurídica é impotente para lidar com a desregulamentação neoliberal e com o poder paralelo

\footnotetext{
13 A esse respeito ver o Artigo de Matthew Jordan: “A quiet place”. Disponível em: https://theconversation.com/our-centuries-long-quest-for-a-quiet-place-94614. Acesso:11/01/2021

14 “Para transformar efetivamente, praticamente, aquilo que descrevemos (timpanizamos), será ainda necessário sermos ouvidos nele e desde então submetermo-nos à lei do martelo interior I? Aceitando a retransmissão do martelo interior, arriscamo-nos então a deixar que o discurso mais ruidoso participe ainda da economia mais serena, menos perturbada, a melhor servida, da ironia filosófica. Isto é, não faltam hoje os exemplos dessa tamborilada metafísica, que, aceitando esse risco, se não arrisca coisa nenhuma. Da filosofia - afastar-se, para lhe descrever e depreciar a lei, em direção à exterioridade absoluta de um outro lugar. Mas a exterioridade, a alteridade, são conceitos que, por si só, nunca surpreenderam o discurso filosófico". DERRIDA. J. Margens da filosofia. Campinas: Papirus, 1991. p.14
} 
miliciano. Trata-se de uma violência estrutural que se estabelece à margem da lei e permanece sem que seja necessariamente ilegal. Mas é possível ouvi-la porquanto seu ruído não cessa. É uma violência que produz suas ressonâncias...

E por isso, ouvindo o Som ao Redor, conclamamos o tímpano - essa estrutura sensível que é a última sensibilizada pelo filme de Mendonça Filho na cena em que as crianças tampam os ouvidos para abafar a bomba acionado pela mãe deles.

Timpanizar essa violência é transitar pelas margens entre ruído e som, ruído e silêncio, silêncio e silenciamento, ouvir e ensurdecer. E aqui permita-nos duas notas: uma que ressoa na esfera jurídico-normativa e outra que ressoa na esfera jurídico-subjetiva.

Na primeira nota, ouvindo o som acadêmico ao redor, como é possível combater a infiltração miliciana?

Luiz Eduardo Soares (2019) afirma que o milicianismo não pode ser enfrentado pela mal-sucedida lógica de guerra ao tráfico. Seja porque as milícias são mais rizomáticas e mais invisíveis que o próprio tráfico de drogas, seja porque a milícia se mantém também em razão do uso excessivo e descomedido da força policial.

Para o antropólogo, a única maneira de combater a milícia é transformar a polícia, primeiramente por uma necessária desmilitarização, e em seguida pelo combate ao "gato orçamentário". Como essa expressão esse autor que indicar o regressivo orçamento de segurança pública dos estados brasileiros na últimas décadas, em especial ao do Rio de Janeiro. Uma força polícial sem recursos, segundo o autor, tende a se submeter a um jogo duplo, associado a práticas paraestatais.

Além de observações de Soares (2019), acrescentaríamos ainda um problema de ordem normativa. A segurança privada no Brasil ainda é uma zona carente de uma regulação mais acurada, causando episódios de violência como o assassinato de um homem preto em supermercado de Porto Alegre por agentes de segurança privada. 
Em outra nota, é preciso repensar quem é o sujeito de direito hoje? O que é a subjetividade jurídica? O que é ter direitos?

No Brasil, o constitucionalismo pós-1988 foi muito eficaz em garantir legislativamente direitos, porém o exercício desses passa a ser obstacularizados por inoperâncias institucionais e estruturais.

No filme de Kleber Mendonça Filho vemos essa cisão - as empregadas domésticas (ainda) têm direito à proteção trabalhista, o direito à aposentadoria, o direito de não ser agredidas, mas não o exercem ou podem exercê-lo. Os moradores têm direito à segurança pública estatal, mas não a exercem.

Chama a atenção no filme, que após o roubo do aparelho de cd-player no carro de Sophia, João percebe que na rua passava uma viatura da polícia, mas não a aciona. Ele prefere, ele mesmo, ir atrás de descobrir quem furtou o som. Aí nota-se como a elite se protege, tolera, minimiza, permite a criminalidade entre os seus: "a lei do Estado é para pobre". João sabe que Dinho é o ladrão. Todos sabem e acobertam Dinho. Ladrão no interdiscurso é pobre e preto. Louro de olhos azuis, rico, tem condutas desviadas que são toleradas. Essa ética às avessas está presente quando João e a namorada aceitam de volta o aparelho roubado, e ainda o aceitam sem que seja o seu próprio. Receptação? Permissões para as classes mais abastadas. A ordem normativa cria sujeitos de direitos "ocos": há a forma, mas não há o conteúdo. Em segundo momento, o sujeito de direito inoperante permite a desregulamentação e a anomia.

No Brasil, nos últimos anos vemos serem suprimidos paulatinamente os direitos trabalhistas, previdenciários, de saúde pública, todos elas contando com uma conivência pública. Isso porque ao não exercerem os direitos previstos, acabam por não reconhecer a importância de mantê-los.

Deixamos emergir uma subjetividade de direito cínica. Como observa Sloterdijk (2012), a subjetividade cínica contemporânea é 
passiva. E assim passividade produz e deixa reproduzir silenciamentos.

Noutro norte ainda, a subjetividade jurídica é substancialmente suprimida por excesso de ruído de nova racionalidade econômica, que funde o oprimido como o opressor. Ao estar constantemente atacado por um comando (interno) de produtividade a subjetividade se rompe permitindo a ascensão das patologias clínicas: depressão, burnout, transtorno bipolar, etc. Um sujeito psicologicamente e difístressado é também um sujeito vazio.

Qual a saída? Há saída? Aqui podemos fazer eco a Chul Han (2017): é preciso reabilitar a potência do silêncio: seja o silêncio do ócio, seja o silêncio filosófico-contemplativo. Esse silêncio não se confunde com o silenciamento, porquanto é mantida da potência da fala.

O Silêncio (maiúsculo, enquanto potência) reivindica a autonomia do sujeito face aos barulhos externo, e esse silêncio que devemos timpanizar, que devemos fazer eco.

\section{Considerações Finais}

A película de Kleber Mendonça Filho retrata as novas formas de poder emergentes na sociedade brasileira na cena contemporânea. Formas de poder que reproduzem o "roteiro" da História brasileira: colonialismo, escravidão, racismo, patriarcalismo, patrimonialismo e violência.

A novidade é a forma: as transformações desse jogo de poder que sai das formas tracionais de vigilância e chega as formas tecnocráticas de controle. Nesse caminhar, o poder estatal passa a ser suplantado, e em certa medida substituído, por uma nova organização de controle: a milícia. A milícia é produto dessa racionalidade cínica brasileira, que não soube ouvir seu passado, e agora produz ressonância e ruídos sobre o presente. 
Esse ruído miliciano produz ainda reverberações sobre a subjetividade brasileira comtemporânea. Somos sujeitos dominados pelos som exteriores - sons que indicam a circulação contínua do capital/poder e da dominação. Nessas ondas sonaras ainda flutuam a racionalidade cínica do patriarcado e do escravagismo, que continua a reproduzir formas de dominação. As personagens femininas do filme sonorização muito bem esse processo. Elas são continuamente silenciadas por essa socidade miliciana de controle.

É preciso, à guisa de consideração final, construir (ou permitir que seja construída) uma nova caixa acústica, uma nova estrutura de audição social que não seja perfurada por esses barulhos excessivo. É preciso que se protejam os tímpanos. Os tímpanos que são órgãos de regulação da passagem do som; são portanto órgão de cuidado - e esse cuidado efeitivo, além do cuidado simulado do colonialismo, que devemos chamar para poder melhor ouvir o som ao redor.

\section{Referências}

ANDRADE, Manuel Correa. Espaço e tempo na agroindústria canavieira de Pernambuco ESTUDOS AVANÇADOS 15 (43), 2001, PP.267 A 280 https://www.scielo.br/scielo.php?script=sci_arttext\&pid=S0103-0142001000300020 Acesso em 10/01/2021.

$B R A U D E L, F$. La Méditerranée et le monde méditerranéen à I'époque de Philippe II. Paris: Armand Colin: 1949.

CESAR FILHO, Francisco. Festival de Cinema Latino-Americano de SP celebra 15 anos com evento on-line e gratuito. Disponível em https://www.youtube.com/watch?v=k-lojEJQDTw. Acesso em 10/01/2021.

CORNELIUS, Ketin. Mílícia Privada e Grupos de Extermínio:

Riscos à Segurança Pública. 2015. Disponível em: https://www. univates.br/bdu/bitstream/10737/1353/1/2016KetinCornelius.pdf. Acesso em: 09 janeiro de 2021. 
DARDOT. P. LAVAL. C. A nova razão do mundo - Ensaio sobre a sociedade neoliberal. São Paulo: Boitempo, 2019.

DERRIDA. J. Margens da filosofia. Campinas: Papirus, 1991.

DELEUZE, G. Conversações, $1^{\text {a }}$ Edição, $3^{a}$ Reimpressão. Trad. Peter Pal Perbart. Editora 34, Rio de Janeiro, 2000.

GUATTARI, F. Caosmose: um novo paradigma estético. São Paulo: Editora 34, 1992.

HAN, B-C. A sociedade do cansaço. São Paulo: Vozes, 2015.

HAN, B-C. A filosofia do zen budismo. São Paulo: Vozes, 2017.

MANSO, Bruno Paes. A Repúlica das Milícias. Dos esquadrões da morte à era Bolsonaro. São Paulo: Todavia, 2019.

MASSON, Ç MARÇAL. V. Organizações Criminosas. Rio de Janeiro:Forense, 2016

MENDONÇA FILHO, Kleber. O som ao redor. O país do cinema. Disponível em https://www.youtube.com/watch?v=ijAl3WcNwQI. Acesso em 10/01/2021.

ORLANDI, Eni P. Interpretação. Autoria, leitura e efeitos do trabalho simbólico. Campinas, Pontes, 2007.

SEGATO. Rita. La guerra contra las mujeres. Buenos Aires, Prometeo Libros, 2018.

SEGATO, Rita. Inventando a natureza: família, sexo e gênero no Xangô do Recife. Anuário Antropológico, 10(1), 11-54.2018. Disponível em https://periodicos.unb.br/index.php/anuarioantropologico/article/view/6352/7677. Acesso: 13.01.2021.

SLOTERDIJK, P. Esferas III. Madrid: Siruela, 2009.

SLOTERDIJK, P. Crítica da Razão Cínica. São Paulo: Estação Liberdade, 2012.

SOARES, L. E. Desmilitarizar: segurança pública e direitos humanos. São Paulo: Boitempo, 2019. 